\title{
Macrophage Tropism in Pathogenic HIV-1 and SIV Infections
}

\author{
Matthew Moeser ${ }^{1}$, Joshua R. Nielsen ${ }^{2}$ and Sarah B. Joseph ${ }^{2, *}$ \\ 1 Lineberger Comprehensive Cancer Center, University of North Carolina at Chapel Hill, \\ Chapel Hill, NC 27599, USA; moeser@ad.unc.edu \\ 2 Department of Microbiology and Immunology, University of North Carolina at Chapel Hill, \\ Chapel Hill, NC 27599, USA; jrniels@med.unc.edu \\ * Correspondence: sbjoseph@email.unc.edu
}

Received: 3 September 2020; Accepted: 23 September 2020; Published: 25 September 2020

check for updates

\begin{abstract}
Most myeloid lineage cells express the receptor and coreceptors that make them susceptible to infection by primate lentiviruses (SIVs and HIVs). However, macrophages are the only myeloid lineage cell commonly infected by SIVs and/or HIVs. The frequency of infected macrophages varies greatly across specific host and virus combinations as well as disease states, with infection rates being greatest in pathogenic SIV infections of non-natural hosts (i.e., Asian nonhuman primates (Asian NHPs)) and late in untreated HIV-1 infection. In contrast, macrophages from natural SIV hosts (i.e., African NHPs) are largely resistant to infection due to entry and/or post-entry restriction mechanisms. These highly variable rates of macrophage infection may stem from differences in the host immune environment, entry and post-entry restriction mechanisms, the ability of a virus to adapt to efficiently infect macrophages, and the pleiotropic effects of macrophage-tropism including the ability to infect cells lacking CD4 and increased neutralization sensitivity. Questions remain about the relationship between rates of macrophage infection and viral pathogenesis, with some evidence suggesting that elevated levels of macrophage infection may contribute to greater pathogenesis in non-natural SIV hosts. Alternatively, extensive infection of macrophages may only emerge in the context of high viral loads and immunodeficiency, making it a symptom of highly pathogenic infections, not a primary driver of pathogenesis.
\end{abstract}

Keywords: SIV; HIV-1; myeloid cells; macrophage; CD4; entry; NHP; tropism

\section{Introduction}

Human immunodeficiency viruses (HIV-1 and HIV-2) and simian immunodeficiency viruses (various SIVs) are primate lentiviruses capable of generating chronic disease in humans and in nonhuman primates (NHPs). SIVs have been replicating in African nonhuman primates for at least 32,000 years [1] and are now highly diverse, with over 40 African NHP species infected with a species-specific SIV [2]. In contrast, HIV-1 and HIV-2 emerged much more recently as separate zoonotic transmissions of SIVs from African primates to humans [3]. Around 1920, the transmission of SIVcpz from chimpanzees to humans generated pandemic HIV-1 [4], which has resulted in tens of millions of deaths. The less pathogenic HIV-2 jumped to humans in the mid-1900s by multiple transmissions of SIV from sooty mangabeys (SIVsm) [5].

The development of antiretroviral therapy (ART) and increased knowledge of HIV biology have saved millions of lives. Much of this progress was made possible by the use of NHP models of HIV infection. SIV infections of African NHPs (their natural hosts) typically generate no disease or disease that is much less pathogenic than HIV-1 infections in humans [6], making these natural hosts poor models of HIV pathogenesis. Fortuitously, after being housed in US primate centers with African NHPs, 
Asian macaques developed immunodeficiency similar to that of HIV-infected people. Eventually, these Asian macaques, which are non-natural hosts of SIVs, were found to have acquired SIV, and the observed disease pathogenesis was similar to that of HIV-infected people, although accelerated [7]. Many NHP models of HIV infection have been developed in which species of Asian macaques are infected with various SIVs.

All primate lentiviruses replicate extensively in CD4+ T-cells, and certain variants are also able to efficiently infect macrophages [8-18]. Macrophage infection is of particular interest given that some macrophages may be able to live for decades [19], making it possible for infected cells to persist for long periods of time and serve as a barrier to curing HIV-infected humans. Furthermore, severe neurocognitive impairment in HIV-infected people may involve viral replication and adaptation in macrophages [12]. Finally, infection of macrophages has been proposed to be a major contributor to overall disease pathogenesis [20]. Addressing these hypotheses has been challenging because macrophages reside in tissues that are difficult to sample in humans. Thus, NHP models are necessary to careful characterize primate lentiviral infection of macrophages.

This review will explore SIV and HIV-1 infection of myeloid lineage cells, particularly macrophages, which are the only myeloid lineage cell type infected at appreciable rates [21-23]. Rates of macrophage infection can reach high levels in the brain during pathogenic infections [20,24] but are typically low. We will focus on humans infected with HIV-1 and SIV-infected Asian macaques (non-natural hosts of SIV), the two systems in which infection of macrophage has been most thoroughly characterized. Additionally, we will examine mechanistic differences in how SIVs and HIVs adapt to infect macrophages. We hypothesize that an improved understanding of macrophage-tropism in SIVs and HIVs may reveal important information about the immune environments in which macrophage-tropic variants evolve and their potential contributions to viral pathogenesis.

\section{Primate Lentiviruses Primarily Replicate in CD4+ T-Cells}

Entry is the first step in infection and is one of the primary determinants of cellular tropism. Primate lentivirus entry (reviewed by [25]) is facilitated by the viral Env protein, which is expressed as a trimer on the virion surface. Entry begins with the binding of the viral Env protein to CD4 on the host cell. After binding to the CD4 surface receptor, Env undergoes conformational changes that expose the V3 loop and form the bridging sheet. The V3 loop and bridging sheet then mediate binding to the coreceptor, and the Env trimer undergoes additional conformational changes that facilitate the fusion of the viral and host cell membranes, allowing the viral capsid to enter the cell.

Given that entry involves the sequential binding of CD4 and a coreceptor, primate lentiviral infection is typically restricted to cells expressing CD4 and a coreceptor (CCR5 or CXCR4, or alternative coreceptors in NHPs) at densities that support viral entry. Studies have repeatedly shown that antibodies or drugs altering viral interactions with CD4 inhibit viral entry and replication in vivo [26-29] and in vitro $[26,30]$, indicating that the CD4 receptor is typically needed for HIV-1 and SIV replication. In humans and in NHPs, CD4 is primarily expressed on CD4+ T-cells [31,32] and myeloid lineage cells (e.g., monocytes, macrophages, and dendritic cells (DCs) $[31,33,34]$ ). Table 1 summarizes receptor and coreceptor expression on these potential target cells in humans and in Asian NHPs. 
Table 1. Receptor and coreceptor expression on a subset of myeloid lineage cells and CD4+ T cells from humans and Asian NHPs.

\begin{tabular}{cccccc}
\hline Species & Potential Target Cells & CD4 & CCR5 & CXCR4 & Citations \\
\hline \multirow{5}{*}{ Humans } & $\begin{array}{c}\text { Monocyte-derived } \\
\text { macrophages (MDM) }\end{array}$ & Positive (Low) & Positive (High) & Positive (Low) & {$[31,33]$} \\
\cline { 2 - 6 } & Tissue macrophages & Positive (Low) & Positive & Positive & {$[35-37]$} \\
\cline { 2 - 6 } & Monocytes & Positive (Low) & Positive (High) & Positive (High) & {$[31,33,34]$} \\
\cline { 2 - 6 } & DCs & Positive (Low) & Positive & Positive & {$[31,38,39]$} \\
\cline { 2 - 6 } & Follicular DCs & Negative & ? & $?$ & {$[40-42]$} \\
\hline \multirow{nyyyyy}{*}{ Memory CD4+ T-cells } & Positive (High) & Positive (High) & Positive (Low) & {$[31]$} \\
\hline & Naïve CD4+ T-cells & Positive (High) & Negative & Positive (High) & {$[31]$} \\
\cline { 2 - 6 } & MDM & Positive & Positive & Positive & {$[14]$} \\
\cline { 2 - 6 } & Tissue macrophages & Positive (Low to undetectable) & Positive & Positive & {$[43,44]$} \\
\cline { 2 - 6 } & DCs & Positive & Positive & $?$ & {$[45]$} \\
\cline { 2 - 6 } & Memory CD4+ T-cells & Positive & Positive & Positive & {$[46]$} \\
\cline { 2 - 6 } & Naïv CD4+ T-cells & Positive & Negative & Positive & {$[46]$} \\
\end{tabular}

\subsection{SIVs and HIV-1 Primarily Replicate in CD4+ T-Cells}

Of their potential target cells, CD4+ T-cells are the primary cells in which HIV-1 and SIVs replicate. The preferential infection of CD4+ T-cells is clearly supported by studies of infected humans and NHPs in which the frequency of CD4+ T-cells containing viral DNA, RNA, or protein is high relative to the low frequency found in monocytes in the blood [21,22] or myeloid cells in tissues [48-50]. This is also supported by in vitro studies showing that most HIV-1 and SIV variants enter and replicate more efficiently in CD4+ T-cells relative to macrophages [14,48,51,52]. The extremely rapid depletion of CD4+ T-cells from gut-associated lymphatic tissue very early in infection [53-58] also reflects the targeting of CD4+ T-cells. However, it is important to note that some of this depletion is likely due to bystander killing, not viral infection (reviewed by [59]). Together, these data indicate that CD4+ T-cells are the primary target cells in SIV and HIV-1 infections.

\subsection{Most Myloid Lineage Cells Are Largely Resistant to HIV-1 and SIV Infection}

Myeloid lineage cells are granulocytes, monocytes, macrophages, and dendritic cells (DCs) [60]. These cells have phagocytic and inflammatory responses to pathogens as well as protective roles in maintaining tissue homeostasis, repairing damage, and influencing development. The majority of myeloid cells are produced by common myeloid progenitors in the bone marrow; however, a subset of tissue-resident macrophages (e.g., microglia in the brain and Kupffer cells in the liver) are produced by erythromyeloid progenitors that colonize tissues during fetal development [61,62].

Monocytes and DCs have been proposed to be potential targets for SIV and HIV replication, but there is no evidence that they are frequently infected [21-23]. While DCs are not directly infected, virions have been observed on the surface or in endosomes of DCs, particularly follicular dendritic cells (fDCs) [63,64], and DCs can transmit virions to CD4+ T-cells [65]. Similarly, monocytes express CD4, albeit at very low levels [31], yet are largely resistant to HIV-1 infection in vitro [66] and infected monocytes are rarely found in the blood of HIV-infected people on [22] or off ART [21]. The resistance of DCs and monocytes to infection is likely derived from both pre-entry blocks (e.g., very low levels of CD4 or CCR5) and post-entry blocks (discussed below).

\subsection{Restriction Factors Limiting Viral Infection in Myeloid Lineage Cells}

Primate lentiviral infection of myeloid lineage cells is thought to be limited by the host protein SAMHD1 (sterile alpha motif and histidine-aspartate domain-containing protein 1), which impairs reverse transcription of the viral RNA genome by reducing nucleotide pools within resting CD4+ T-cells 
and myeloid cells $[67,68]$. HIV-2 and some SIV variants, including those derived from SIVsm, express the Vpx protein, which targets SAMHD1 for proteasome-mediated degradation, thus increasing viral replication in myeloid cells and in resting CD4+ T-cells [68,69]. HIV-1 and some other SIVs lack the $v p x$ gene but express the accessory protein Vpr, which may also inhibit SAMHD1 [70].

Studies examining the role that SAMHD1 plays in infection of myeloid cells suggest that SAMHD1 restriction alone does not explain the extremely low levels of myeloid cell infection in vivo. One experiment comparing macaques infected with either an SIV expressing Vpx or with a vpx deletion mutant found that the Vpx expressing SIV infected macrophages at higher rates, suggesting that Vpx does enhance infection of myeloid lineage cells in vivo [71]. However, Vpx also increased the overall pathogenesis of infections, making it difficult to ascertain whether elevated rates of macrophage infection were mediated by Vpx degradation of SAMHD1 or overall disease pathogenesis. In contrast, another study comparing infections initiated with SIVmac239 and SIVmac239 $\Delta v$ px observed that expression of Vpx had little effect on the amount of DNA in myeloid lineage cells and found that much of the viral DNA detected in macrophages was due to the phagocytosis of infected T-cells [48]. The low levels of infection observed in myeloid cells, even in the presence of $\mathrm{Vpx}$, could be explained by an inability of Vpx to overcome SAMHD1 completely [72], other post-entry restriction factors, or by CD4 and/or coreceptor densities that are too low to facilitate efficient entry.

\section{HIV-1 Infection of Macrophage}

\subsection{HIV-1 Primarily Infects Macrophages When CD4+ T-Cells Are Limited}

The frequency of macrophage infection is highly variable in HIV-infected people but is consistently higher in pathogenic infections late in the disease. This is most clearly illustrated by studies examining HIV-1 populations in the immune-privileged CNS at end-stage disease. Immunostaining of brain tissue from such individuals has identified large numbers of productively infected microglia [73-76] and CNS macrophages [73,77]. HIV-1 infection of macrophages in the CNS is also supported by genetic analyses of virus populations in the cerebrospinal fluid (CSF) and blood. Early in infection, HIV-1 populations in the blood and CSF are typically closely related [78], but as the disease progresses, genetically distinct viral populations (i.e., compartmentalized populations) can emerge in the CSF $[9,11,12]$. Studies have also found that unlike populations in the blood, compartmentalized populations in the CSF are occasionally well adapted to infecting macrophages/microglia [8-13,79-82] (in this review, we will not deal with the important question of whether CNS macrophages and microglia are both targets for HIV-1 infection and, if so, are they equally infected). Such compartmentalized, macrophage-tropic populations emerge due to sustained viral replication and adaptation in macrophages/microglia in the CNS, a phenotype that may be favored in the CNS where CD4+ T-cells are rare and late in disease when CD4+ T cell counts are low. HIV-1 has also been observed to infect alveolar macrophages in the lungs [83], urethral macrophages in penile tissue [84], and liver macrophages [85].

\subsection{Macrophage-Tropic HIV-1 Has an Enhanced Ability to Infect Cells Expressing a Low Surface Density of $C D 4$}

Multiple studies have shown that the vast majority of HIV-1 variants throughout the body, and virtually all HIV-1 variants in the blood, are poorly adapted to infecting macrophages (i.e., are T-cell-tropic) and require high CD4 densities similar to the levels on CD4+ T-cells for efficient entry ([86,87]; reviewed in [88]). However, a small subset of HIV-1 variants is able to efficiently enter macrophages (i.e., are macrophage-tropic) and has an enhanced ability to infect cells expressing a low surface density of CD4 [9,11,12,79-82]. This phenotype facilitates the infection of macrophages that express a low density of CD4 on their surface [31,89].

Macrophage-tropic HIV-1 can occasionally be isolated from humans, and these variants are able to efficiently infect cells expressing low CD4 densities, but in vitro analyses indicate that they do not have the ability to efficiently infect cells lacking CD4 [89]. This is difficult to reconcile with observations 
that HIV-1 occasionally infects kidney epithelial cells [90,91] and astrocytes [92-95], both of which lack CD4. The most likely explanation is that HIV-1 infects these cells via a highly inefficient mechanism that allows HIV-1 to enter cells without first binding CD4. The efficiency of CD4-independent entry can be improved by passaging HIV-1 in tissue culture [96-99]. The resulting tissue-culture-adapted variants have been observed to have an enhanced ability to infect cells lacking CD4 and an open Env conformation that greatly increases their neutralization sensitivity, which likely explains why they are not observed in vivo [100,101]. Together, these results indicate that it is possible for HIV-1 to evolve the ability to efficiently infect cells lacking CD4, but that natural selection does not favor this phenotype in humans.

\section{Infection of Macrophages in Pathogenic SIV Infections of Non-Natural Hosts (Asian NHPs)}

Many common NHP models generate at least some macrophage infection in vivo (see Table 2), but levels of macrophage infection are greatly elevated in models where T-cells are rapidly depleted either by a highly pathogenic viral swarm [102-105] or by antibody depletion of CD4+ or CD8+ T-cells [106,107]. Table 2 summarizes the methods used to generate some of the SIVs most commonly used in NHP models of HIV and their tropism in vivo and in vitro.

Table 2. Macrophage tropism of SIVs commonly used in NHP models of HIV infection.

\begin{tabular}{|c|c|c|c|c|}
\hline Virus & Source & $\begin{array}{l}\text { Infect Macaque } \\
\text { Macrophage } \\
\text { In Vitro }\end{array}$ & $\begin{array}{l}\text { Efficiently Infect } \\
\text { Macaque Macrophage } \\
\text { In Vivo }\end{array}$ & $\begin{array}{c}\text { Able to Infect } \\
\text { Cells Lacking CD4 }\end{array}$ \\
\hline SIVmac251 & $\begin{array}{l}\text { Spleen cells were collected from an } \\
\text { SIV-infected macaque who developed } \\
\text { AIDS and then cultured in vitro. } \\
\text { SIVmac251 is a viral swarm initially } \\
\text { collected from this cell supernatant } \\
\text { and amplified in macaque } \\
\text { cells }[108,109]\end{array}$ & Yes, MDM [110] & $\begin{array}{c}\text { Conflicting data, but } \\
\text { clearly replicates when } \\
\text { CD4+ or CD8+ T-cells are } \\
\text { depleted }[106,107,111,112]\end{array}$ & Yes [15] \\
\hline SIVmac239 & $\begin{array}{l}\text { Tissue from the infected animal used } \\
\text { to derive SIVmac } 251 \text { was in vivo } \\
\text { passaged through additional } \\
\text { macaques. Plasma from one of these } \\
\text { animals was used to infect cells } \\
\text { in vitro, and an infectious molecular } \\
\text { clone was generated from the culture } \\
\text { supernatant }[108,109,113]\end{array}$ & No, MDM [14,114] & Yes $[115,116]$ & No $[14,18]$ \\
\hline SIVmac316 & $\begin{array}{l}\text { Alveolar macrophages (AM) were } \\
\text { collected from a macaque infected } \\
\text { with a SIVmac239-derived isolate. } \\
\text { The AM were cultured in vitro and } \\
\text { SIVmac316 was isolated from } \\
\text { supernatant }[117,118]\end{array}$ & $\begin{array}{l}\text { Yes, alveolar } \\
\text { macrophages and } \\
\text { MDM }[14,117]\end{array}$ & No [115] & Yes $[14,18]$ \\
\hline SIV/17E-Fr & $\begin{array}{l}\text { SIVmac } 239 \text { was passaged in } \\
\text { macaques with brain homogenate } \\
\text { from the first animal being used to } \\
\text { infect the second. SIV/17E-Br was } \\
\text { isolated from the brain of the second } \\
\text { animal after it developed neurologic } \\
\text { disease. The env, nef, and the } 3 \text { ' LTR } \\
\text { of SIV/17E-Br were cloned into } \\
\text { SIVmac239 to generate } \\
\text { SIV/17E-Fr }[52,119,120]\end{array}$ & Yes, MDM [52,120] & $\begin{array}{l}\text { Yes [121], but infection is } \\
\text { greatly enhanced in } \\
\text { animals coinfected with } \\
\text { SIV/DeltaB670 [122,123]. }\end{array}$ & Yes [15-18] \\
\hline SIVsmE543-3 & $\begin{array}{l}\text { Uncloned SIVsmF236 was used to } \\
\text { inoculate a macaque who developed } \\
\text { neurological disease. PBMCs were } \\
\text { collected from this animal at the time } \\
\text { of necropsy, and cell-associated virus } \\
\text { was expanded in CEMx174 cells and } \\
\text { then cloned to yield } \\
\text { SIVsmE543-3 [124] }\end{array}$ & $\begin{array}{l}\text { Yes, MDM } \\
{[124-126]}\end{array}$ & Yes [124] & No [15] \\
\hline SIVsm804E-CL757 & $\begin{array}{c}\text { SIVsmE543-3 was sequentially } \\
\text { passaged in } 4 \text { rhesus macaques, and } \\
\text { virus was isolated from the brain after } \\
\text { passage }[125,126]\end{array}$ & $\begin{array}{c}\text { Yes, MDM } \\
{[125,126]}\end{array}$ & Yes [127] & $?$ \\
\hline
\end{tabular}


Macrophage-Tropic SIVs often Have the Ability to Infect Cells Lacking CD4

A common feature of both macrophage-tropic HIV-1 and SIV variants is that they have an increased ability to infect cells expressing low levels of CD4 [9,11,12,14,79-82], but they differ in a number of important ways. Most notably, macrophage-tropic SIVs are typically able to infect cells lacking CD4 [14-18], while patient-derived HIV-1 variants always require CD4 for efficient entry [89]. In addition, most macrophage-tropic SIVs are highly sensitive to neutralization [128]. This is illustrated by the observation that greater CD4-independence among SIV Envs is associated with increased neutralization sensitivity [18], suggesting that mutations that increase CD4-independence also expose epitopes. In contrast, patient-derived, macrophage-tropic HIV-1 is not significantly more sensitive to broadly neutralizing antibodies (bNABs) than T-cell-tropic HIV-1 [129].

The neutralization sensitivity of CD4-independent SIV Envs likely stems from continuous exposure of their coreceptor binding site [98]. This conformation allows CD4-independent Envs to bind their coreceptor without first binding CD4, thus facilitating entry into cells lacking CD4. Interestingly, macaques that are not CD4-depleted before infection and people chronically infected with HIV-1 have antibodies that recognize epitopes that are exposed on CD4-independent Envs [130,131], suggesting that CD4-independent Envs may be selected against in immunocompetent NHPs and in chronically-infected humans. There are, however, conditions where CD4-independent SIVs may have a fitness advantage. Specifically, when NHPs are infected with a macrophage-tropic SIV capable of efficient CD4-independent entry and are immunosuppressed, the resulting infections are often highly pathogenic, with large numbers of infected macrophages [106,107,111,122,123]. Under these conditions, immunosuppression may allow macrophage-tropic SIVs to evade immune recognition and colonize macrophage-rich tissues such as the CNS.

While many of the most commonly studied macrophage-tropic SIVs are capable of CD4independent entry (Table 2), in vitro analyses of SIVsmE543-3, which was derived from a macaque with SIV-induced encephalitis, indicate that this variant is macrophage-tropic but retains the need for CD4 to efficiently enter host cells [15], thus raising the possibility that macrophage-tropic SIVs may either evolve under conditions that select for variants that are CD4-independent or under conditions that select for variants that are dependent on CD4 for efficient entry. This pattern could emerge if CD4-independent variants are only favored in highly pathogenic NHP infections with severe immunodeficiency. Alternatively, these two types of macrophage-tropic SIVs may represent different evolutionary pathways that evolved independently under the same selection pressures.

Consistent with the notion that macrophage-tropic Envs may be under intense immune pressure in immunocompetent hosts, SIV variants that are macrophage-tropic in vitro do not always generate extensive macrophage infection in vivo [115]. For example, a study examining animals infected with a variant that is macrophage-tropic in vitro (SIVmac316) found that the macrophage-tropic variant poorly infected macrophage in vivo. This discrepancy may partially reflect the fact that the macrophage-tropic variant was both highly sensitive to neutralization [128] and generated a less pathogenic infection with a much lower set-point viral load [115]. Thus, immune recognition of this neutralization-sensitive variant may have kept viral loads low and precluded viral colonization of macrophage-rich tissues.

While CD4-independent SIVs can replicate in vivo, they rarely infect cells lacking CD4. One exception is a pathogenic model in which pig-tailed macaques are coinfected with a highly immunosuppressive SIV viral swarm and a macrophage-tropic clone $[15,16]$. In this model, the virus frequently infects brain endothelial cells that lack CD4 $[15,16]$. The paucity of SIV-infected, CD4-negative cells in other model systems may indicate that CD4-independent entry is highly inefficient in vivo or that the phenotype is rapidly lost as the viral population adapts to the host environment.

\section{Infection of Macrophages in Nonpathogenic SIV Infections of Natural Hosts (African NHPs)}

SIV infection of natural hosts typically generates high levels of viral replication without progression to AIDS [6,132]. There are likely many factors that reduce SIV pathogenesis in natural hosts [132], with one hypothesis being that pathogenesis is reduced by blocking macrophage infection [20]. 


\subsection{CD4-Dependence of SIV in Natural Hosts}

SIVs are highly diverse and their cellular tropism has only been directly examined in a small number of natural hosts, but the available evidence suggests that CD4 usage is conserved in SIV infections of natural hosts [133,134]. For example, SIVs from sooty mangabeys (SIVsm and SIVsmmPBj) $[133,134]$ and African green monkeys (SIVagm) [134] have been shown to require CD4 for entry. In contrast, coreceptor usage is less conserved, as illustrated by SIVrcm (from red-capped mangabeys), which utilizes the alternative coreceptor, CCR2 [135].

\subsection{There are Substantial Blocks to SIV Infection of Macrophage in Their Natural Hosts}

SIV-infected African NHPs typically do not experience highly pathogenic infections, and their macrophages are largely resistant to infection, thus raising the possibility that blocks to macrophage infection may help these natural hosts avoid the pathogenic effects of SIV. Mir et al. [20] assessed this hypothesis by comparing the ability of SIVm949 to infect MDM from natural hosts (sooty mangabeys) and non-natural hosts (rhesus macaques). SIVm949 replicated well in MDM from non-natural hosts, but poorly in MDM from natural hosts, despite the fact that it replicated equally well in PBMCs from the two hosts. This clearly illustrates a block in the ability of SIVm949 to infect MDM from the natural host. In order to further explore the mechanisms blocking macrophage (but not CD4+ T-cell) infection in the natural host, the authors quantified the expression of host restriction factors and found that multiple restriction factors (including tetherin and TRIM22) were expressed at higher levels in the natural host.

Are these blocks to macrophage infection in natural SIV hosts also observed in vivo? In a study of SIV-infected sooty mangabeys, depletion of CD4+ T-cells (but not macrophages) resulted in reduced plasma viral loads [136]. In contrast, depletion of CD4+ T-cells (but not macrophages) from non-natural hosts prior to infection resulted in extremely high viral loads, rapid progression to AIDS, and extensive infection of macrophages and microglia. These results indicate that SIV-infected macrophages can produce large amounts of virus in non-natural hosts but may contribute little to viremia in natural hosts [106,111]. Variation in macrophage tropism across natural hosts is unknown, however, analyses of genetic diversity in CD4 genes across African NHPs have identified extensive variation [137] that could potentially alter viral tropism, including macrophage tropism.

There is now both in vitro and in vivo data indicating that SIV infection of macrophages is blocked in natural hosts, but not in non-natural hosts. The ability of SIV to enter macrophages from non-natural hosts depends on the surface density of CD4 [14], but studies have not examined whether increasing CD4 expression facilitates entry into macrophages from natural hosts. Such information would be helpful to explore the contribution that pre- and post-entry mechanisms make to this block in macrophage infection.

\section{Conclusions}

SIVs are capable of generating a wide range of disease states, with highly variable levels of macrophage infection. Our understanding of how natural hosts are protected from the pathogenic effects of SIV infection remains unclear, but there is growing data suggesting that blocks to macrophage infection in natural hosts may contribute to this protection. However, the fact that some highly pathogenic SIV and HIV-1 infections do not generate high levels of macrophage infection suggests that extensive macrophage infection is not a requirement for the development of pathogenic infections. An alternative hypothesis is that extensive infection of macrophages is a symptom of highly pathogenic infections. Additional work is needed to untangle the mechanistic link between pathogenesis and infection of macrophages in primate lentiviruses. 
Author Contributions: Conceptualization, M.M., J.R.N. and S.B.J.; writing-original draft preparation, M.M., J.R.N. and S.B.J.; writing-review and editing, M.M., J.R.N. and S.B.J.; funding acquisition, S.B.J. All authors have read and agreed to the published version of the manuscript.

Funding: This work was supported by NIH grant R01-MH118990 to S.B.J. The work was also supported by the UNC Center for AIDS Research (NIH award P30 AI050410) and the UNC Lineberger Comprehensive Cancer Center (NIH award P30 CA16068).

Acknowledgments: We would like to thank Adrienne Swanstrom, Greg Del Prete, and Ronald Swanstrom for helpful discussions.

Conflicts of Interest: The authors declare no conflict of interest.

\section{References}

1. Worobey, M.; Telfer, P.; Souquiere, S.; Hunter, M.; Coleman, C.A.; Metzger, M.J.; Reed, P.; Makuwa, M.; Hearn, G.; Honarvar, S.; et al. Island biogeography reveals the deep history of SIV. Science 2010, 329, 1487. [CrossRef]

2. Peeters, M.; Ma, D.Z.; Liegeois, F.; Apetrei, C. Simian Immunodeficiency Virus Infections in the Wild; Elsevier Academic Press Inc.: San Diego, CA, USA, 2014; pp. 37-67.

3. Hahn, B.H.; Shaw, G.M.; De Cock, K.M.; Sharp, P.M. AIDS as a zoonosis: Scientific and public health implications. Science 2000, 287, 607-614. [CrossRef] [PubMed]

4. Worobey, M.; Gemmel, M.; Teuwen, D.E.; Haselkorn, T.; Kunstman, K.; Bunce, M.; Muyembe, J.J.; Kabongo, J.M.M.; Kalengayi, R.M.; Van Marck, E.; et al. Direct evidence of extensive diversity of HIV-1 in Kinshasa by 1960. Nature 2008, 455, 661-664. [CrossRef] [PubMed]

5. Lemey, P.; Pybus, O.G.; Wang, B.; Saksena, N.K.; Salemi, M.; Vandamme, A.M. Tracing the origin and history of the HIV-2 epidemic. Proc. Natl. Acad. Sci. USA 2003, 100, 6588-6592. [CrossRef] [PubMed]

6. Klatt, N.R.; Silvestri, G.; Hirsch, V. Nonpathogenic Simian Immunodeficiency Virus Infections. Cold Spring Harb. Perspect. Med. 2012, 2, a007153. [CrossRef]

7. Gardner, M.B. The history of simian AIDS. J. Med. Primatol. 1996, 25, 148-157. [CrossRef]

8. Gorry, P.R.; Bristol, G.; Zack, J.A.; Ritola, K.; Swanstrom, R.; Birch, C.J.; Bell, J.E.; Bannert, N.; Crawford, K.; Wang, H.; et al. Macrophage tropism of human immunodeficiency virus type 1 isolates from brain and lymphoid tissues predicts neurotropism independent of coreceptor specificity. J. Virol. 2001, 75, 10073-10089. [CrossRef]

9. Gorry, P.R.; Taylor, J.; Holm, G.H.; Mehle, A.; Morgan, T.; Cayabyab, M.; Farzan, M.; Wang, H.; Bell, J.E.; Kunstman, K.; et al. Increased CCR5 affinity and reduced CCR5/CD4 dependence of a neurovirulent primary human immunodeficiency virus type 1 isolate. J. Virol. 2002, 76, 6277-6292. [CrossRef]

10. Li, S.; Juarez, J.; Alali, M.; Dwyer, D.; Collman, R.; Cunningham, A.; Naif, H.M. Persistent CCR5 utilization and enhanced macrophage tropism by primary blood human immunodeficiency virus type 1 isolates from advanced stages of disease and comparison to tissue-derived isolates. J. Virol. 1999, 73, 9741-9755. [CrossRef]

11. Peters, P.J.; Bhattacharya, J.; Hibbitts, S.; Dittmar, M.T.; Simmons, G.; Bell, J.; Simmonds, P.; Clapham, P.R. Biological analysis of human immunodeficiency virus type 1 R5 envelopes amplified from brain and lymph node tissues of AIDS patients with neuropathology reveals two distinct tropism phenotypes and identifies envelopes in the brain that confer an enhanced tropism and fusigenicity for macrophages. J. Virol. 2004, $78,6915-6926$.

12. Schnell, G.; Joseph, S.; Spudich, S.; Price, R.W.; Swanstrom, R. HIV-1 replication in the central nervous system occurs in two distinct cell types. PLoS Pathog. 2011, 7, e1002286. [CrossRef]

13. Koyanagi, Y.; Miles, S.; Mitsuyasu, R.T.; Merrill, J.E.; Vinters, H.V.; Chen, I.S.Y. Dual infection of the central nervous system by AIDS viruses with distinct cellular tropisms. Science 1987, 236, 819-822. [CrossRef]

14. Bannert, N.; Schenten, D.; Craig, S.; Sodroski, J. The level of CD4 expression limits infection of primary rhesus monkey macrophages by a T-tropic simian immunodeficiency virus and macrophagetropic human immunodeficiency viruses. J. Virol. 2000, 74, 10984-10993. [CrossRef] [PubMed]

15. Edinger, A.L.; Mankowski, J.L.; Doranz, B.J.; Margulies, B.J.; Lee, B.; Rucker, J.; Sharron, M.; Hoffman, T.L.; Berson, J.F.; Zink, M.C.; et al. CD4-independent, CCR5-dependent infection of brain capillary endothelial cells by a neurovirulent simian immunodeficiency virus strain. Proc. Natl. Acad. Sci. USA 1997, 94, 14742-14747. [CrossRef] [PubMed] 
16. Mankowski, J.L.; Spelman, J.P.; Ressetar, H.G.; Strandberg, J.D.; Laterra, J.; Carter, D.L.; Clements, J.E.; Zink, M.C. Neurovirulent simian immunodeficiency virus replicates productively in endothelial cells of the central nervous system in vivo and in vitro. J. Virol. 1994, 68, 8202-8208. [CrossRef] [PubMed]

17. Overholser, E.D.; Babas, T.; Zink, M.C.; Barber, S.A.; Clements, J.E. CD4-independent entry and replication of simian immunodeficiency virus in primary rhesus macaque astrocytes are regulated by the transmembrane protein. J. Virol. 2005, 79, 4944-4951. [CrossRef] [PubMed]

18. Puffer, B.A.; Pohlmann, S.; Edinger, A.L.; Carlin, D.; Sanchez, M.D.; Reitter, J.; Watry, D.D.; Fox, H.S.; Desrosiers, R.C.; Doms, R.W. CD4 independence of simian immunodeficiency virus Envs is associated with macrophage tropism, neutralization sensitivity, and attenuated pathogenicity. J. Virol. 2002, 76, 2595-2605. [CrossRef]

19. Reu, P.; Khosravi, A.; Bernard, S.; Mold, J.E.; Salehpour, M.; Alkass, K.; Perl, S.; Tisdale, J.; Possnert, G.; Druid, H.; et al. The lifespan and turnover of microglia in the human brain. Cell Rep. 2017, 20, 779-784. [CrossRef]

20. Mir, K.D.; Mavigner, M.; Wang, C.; Paiardini, M.; Sodora, D.L.; Chahroudi, A.M.; Bosinger, S.E.; Silvestri, G. Reduced Simian Immunodeficiency Virus replication in macrophages of sooty mangabeys is associated with increased expression of host restriction factors. J. Virol. 2015, 89, 10136-10144. [CrossRef]

21. Josefsson, L.; King, M.S.; Makitalo, B.; Brannstrom, J.; Shao, W.; Maldarelli, F.; Kearney, M.F.; Hu, W.S.; Chen, J.B.; Gaines, H.; et al. Majority of CD4(+) T cells from peripheral blood of HIV-1-infected individuals contain only one HIV DNA molecule. Proc. Natl. Acad. Sci. USA 2011, 108, 11199-11204. [CrossRef]

22. Massanella, M.; Bakeman, W.; Sithinamsuwan, P.; Fletcher, J.L.K.; Chomchey, N.; Tipsuk, S.; Chalermchai, T.; Routy, J.P.; Ananworanich, J.; Valcour, V.G.; et al. Infrequent HIV Infection of Circulating Monocytes during Antiretroviral Therapy. J. Virol. 2020, 94, 14. [CrossRef]

23. Wu, L.; KewalRamani, V.N. Dendritic-cell interactions with HIV: Infection and viral dissemination. Nat. Rev. Immunol. 2006, 6, 859-868. [CrossRef]

24. Zhou, L.; Rua, R.; Ng, T.; Vongrad, V.; Ho, Y.S.; Geczy, C.; Hsu, K.; Brew, B.J.; Saksena, N.K. Evidence for predilection of macrophage infiltration patterns in the deeper midline and mesial temporal structures of the brain uniquely in patients with HIV-associated dementia. BMC Infect. Dis. 2009, 9, 192. [CrossRef]

25. Chen, B. Molecular Mechanism of HIV-1 Entry. Trends. Microbiol. 2019, 27, 878-891. [CrossRef] [PubMed]

26. Dalgleish, A.G.; Beverley, P.C.L.; Clapham, P.R.; Crawford, D.H.; Greaves, M.F.; Weiss, R.A. The CD4 (T4) antigen is an essential component of the receptor for the AIDS retrovirus. Nature 1984, 312, 763-767. [CrossRef] [PubMed]

27. Jacobson, J.M.; Lowy, I.; Fletcher, C.V.; O’Neill, T.J.; Tran, D.N.H.; Ketas, T.J.; Trkola, A.; Klotman, M.E.; Maddon, P.J.; Olson, W.C.; et al. Single-dose safety, pharmacology, and antiviral activity of the human immunodeficiency virus (HIV) type 1 entry inhibitor PRO 542 in HIV-infected adults. J. Infect. Dis. 2000, 182, 326-329. [CrossRef] [PubMed]

28. Kuritzkes, D.R.; Jacobson, J.; Powderly, W.G.; Godofsky, E.; DeJesus, E.; Haas, F.; Reimann, K.A.; Larson, J.L.; Yarbough, P.O.; Curt, V.; et al. Antiretroviral activity of the anti-CD4 monoclonal antibody TNX-355 in patients infected with HIV type 1. J. Infect. Dis. 2004, 189, 286-291. [CrossRef]

29. Reimann, K.A.; Lin, W.Y.; Bixler, S.; Browning, B.; Ehrenfels, B.N.; Lucci, J.; Miatkowski, K.; Olson, D.; Parish, T.H.; Rosa, M.D.; et al. A humanized form of a CD4-specific monoclonal antibody exhibits decreased antigenicity and prolonged plasma half-life in rhesus monkeys while retaining its unique biological and antiviral properties. AIDS Res. Hum. Retrovir. 1997, 13, 933-943. [CrossRef]

30. Klatzmann, D.; Champagne, E.; Chamaret, S.; Gruest, J.; Guetard, D.; Hercend, T.; Gluckman, J.C.; Montagnier, L. T-lymphocyte T4 molecule behaves as the receptor for human retrovirus LAV. Nature 1984, 312, 767-768. [CrossRef]

31. Lee, B.; Sharron, M.; Montaner, L.J.; Weissman, D.; Doms, R.W. Quantification of CD4, CCR5, and CXCR4 levels on lymphocyte subsets, dendritic cells, and differentially conditioned monocyte-derived macrophages. Proc. Natl. Acad. Sci. USA 1999, 96, 5215-5220. [CrossRef]

32. Ellmeier, W.; Sawada, S.; Littman, D.R. The regulation of CD4 and CD8 coreceptor gene expression during T cell development. Annu. Rev. Immunol. 1999, 17, 523-554. [CrossRef] [PubMed]

33. Kazazi, F.; Mathijs, J.M.; Foley, P.; Cunningham, A.L. Variations in CD4 Expression by Human Monocytes and Macrophages and Their Relationships to Infection With the Human Immunodeficiency Virus. J. Gen. Virol. 1989, 70, 2661-2672. [CrossRef] [PubMed] 
34. Wood, G.S.; Warner, N.L.; Warnke, R.A. Anti-Leu-3/T4 antibodies react with cells of monocyte/macrophage and Langerhans lineage. J. Immunol. 1983, 131, 212-216. [PubMed]

35. Cenker, J.J.; Stultz, R.D.; McDonald, D. Brain microglial cells are highly susceptible to HIV-1 infection and spread. AIDS Res. Hum. Retrovir. 2017, 33, 1155-1165. [CrossRef]

36. Albright, A.V.; Shieh, J.T.C.; Itoh, T.; Lee, B.; Pleasure, D.; O'Connor, M.J.; Doms, R.W.; Gonzalez-Scarano, F. Microglia express CCR5, CXCR4, and CCR3, but of these, CCR5 is the principal coreceptor for human immunodeficiency virus type 1 dementia isolates. J. Virol. 1999, 73, 205-213. [CrossRef] [PubMed]

37. Dick, A.D.; Pell, M.; Brew, B.J.; Foulcher, E.; Sedgwick, J.D. Direct ex vivo flow cytometric analysis of human microglial cell CD4 expression: Examination of central nervous system biopsy specimens from HIV-seropositive patients and patients with other neurological disease. AIDS 1997, 11, 1699-1708. [CrossRef]

38. Damasceno, D.; Andres, M.P.; van den Bossche, W.B.L.; Flores-Montero, J.; de Bruin, S.; Teodosio, C.; van Dongen, J.J.M.; Orfao, A.; Almeida, J. Expression profile of novel cell surface molecules on different subsets of human peripheral blood antigen-presenting cells. Clin. Transl. Immunol. 2016, 5, e100. [CrossRef]

39. Jardine, L.; Barge, D.; Ames-Draycott, A.; Pagan, S.; Cookson, S.; Spickett, G.; Haniffa, M.; Collin, M.; Bigley, V. Rapid detection of dendritic cell and monocyte disorders using CD4 as a lineage marker of the human peripheral blood antigen-presenting cell compartment. Front. Immunol. 2013, 4, 495. [CrossRef]

40. Stahmer, I.; Zimmer, J.P.; Ernst, M.; Fenner, T.; Finnern, R.; Schmitz, H.; Flad, H.D.; Gerdes, J. Isolation of normal human follicular dendritic cells and CD4-independent in vitro infection by human immunodeficiency virus (HIV-1). Eur. J. Immunol. 1991, 21, 1873-1878. [CrossRef]

41. Sellheyer, K.; Schwarting, R.; Stein, H. Isolation and antigenic profile of follicular dendritic cells. Clin. Exp. Immunol. 1989, 78, 431-436.

42. Schriever, F.; Freeman, G.; Nadler, L.M. Follicular dendritic cells contain a unique gene repertoire demonstrated by single-cell polymerase chain reaction. Blood 1991, 77, 787-791. [CrossRef] [PubMed]

43. Westmoreland, S.V.; Alvarez, X.; de Bakker, C.; Aye, P.; Wilson, M.L.; Williams, K.C.; Lackner, A.A. Developmental expression patterns of CCR5 and CXCR4 in the rhesus macaque brain. J. Neuroimmunol. 2002, 122, 146-158. [CrossRef]

44. Mori, K.; Rosenzweig, M.; Desrosiers, R.C. Mechanisms for adaptation of simian immunodeficiency virus to replication in alveolar macrophages. J. Virol. 2000, 74, 10852-10859. [CrossRef] [PubMed]

45. Xia, H.J.; Ma, J.P.; Zhang, G.H.; Han, J.B.; Wang, J.H.; Zheng, Y.T. Effect of Plasma Viremia on Apoptosis and Immunophenotype of Dendritic Cells Subsets in Acute SIVmac239 Infection of Chinese Rhesus Macaques. PLoS ONE 2011, 6, e29036. [CrossRef]

46. Nishimura, Y.; Igarashi, T.; Donau, O.K.; Buckler-White, A.; Buckler, C.; Lafont, B.A.P.; Goeken, R.M.; Goldstein, S.; Hirsch, V.M.; Martin, M.A. Highly pathogenic SHIVs and SIVs target different CD4+ T cell subsets in rhesus monkeys, explaining their divergent clinical courses. Proc. Natl. Acad. Sci. USA 2004, 101, 12324-12329. [CrossRef]

47. Bissel, S.J.; Wang, G.; Trichel, A.M.; Murphey-Corb, M.; Wiley, C.A. Longitudinal analysis of activation markers on monocyte subsets during the development of simian immunodeficiency virus encephalitis. J. Neuroimmunol. 2006, 177, 85-98. [CrossRef]

48. Calantone, N.; Wu, F.; Klase, Z.; Deleage, C.; Perkins, M.; Matsuda, K.; Thompson, E.A.; Ortiz, A.M.; Vinton, C.L.; Ourmanov, I.; et al. Tissue myeloid cells in SIV-infected primates acquire viral DNA through phagocytosis of infected T cells. Immunity 2014, 41, 493-502. [CrossRef]

49. Deleage, C.; Wietgrefe, S.W.; Del Prete, G.; Morcock, D.R.; Hao, X.P.; Piatak, M.J.; Bess, J.; Anderson, J.L.; Perkey, K.E.; Reilly, C.; et al. Defining HIV and SIV Reservoirs in Lymphoid Tissues. Pathog. Immun. 2016, 1, 68-106. [CrossRef]

50. McIlroy, D.; Autran, B.; Cheynier, R.; Wainhobson, S.; Clauvel, J.P.; Oksenhendler, E.; Debre, P.; Hosmalin, A. Infection frequency of dendritic cells and CD4+ T lymphocytes in spleens of human immunodeficiency virus-positive patients. J. Virol. 1995, 69, 4737-4745. [CrossRef]

51. Ochsenbauer, C.; Edmonds, T.G.; Ding, H.T.; Keele, B.F.; Decker, J.; Salazar, M.G.; Salazar-Gonzalez, J.F.; Shattock, R.; Haynes, B.F.; Shaw, G.M.; et al. Generation of transmitted/founder HIV-1 infectious molecular clones and characterization of their replication capacity in CD4 T lymphocytes and monocyte-derived macrophages. J. Virol. 2012, 86, 2715-2728. [CrossRef] [PubMed] 
52. Sharma, D.P.; Zink, M.C.; Anderson, M.; Adams, R.; Clements, J.E.; Joag, S.V.; Narayan, O. Derivation of neurotropic simian immunodeficiency virus from exclusively lymphocytetropic parental virus: Pathogenesis of infection in macaques. J. Virol. 1992, 66, 3550-3556. [CrossRef] [PubMed]

53. Brenchley, J.M.; Schacker, T.W.; Ruff, L.E.; Price, D.A.; Taylor, J.H.; Beilman, G.J.; Nguyen, P.L.; Khoruts, A.; Larson, M.; Haase, A.T.; et al. CD4(+) T cell depletion during all stages of HIV disease occurs predominantly in the gastrointestinal tract. J. Exp. Med. 2004, 200, 749-759. [CrossRef] [PubMed]

54. Guadalupe, M.; Reay, E.; Sankaran, S.; Prindiville, T.; Flamm, J.; McNeil, A.; Dandekar, S. Severe CD4(+) T-cell depletion in gut lymphoid tissue during primary human immunodeficiency virus type 1 infection and substantial delay in restoration following highly active antiretroviral therapy. J. Virol. 2003, 77, 11708-11717. [CrossRef] [PubMed]

55. Mehandru, S.; Poles, M.A.; Tenner-Racz, K.; Horowitz, A.; Hurley, A.; Hogan, C.; Boden, D.; Racz, P.; Markowitz, M. Primary HIV-1 infection is associated with preferential depletion of CD4(+) T lymphocytes from effector sites in the gastrointestinal tract. J. Exp. Med. 2004, 200, 761-770. [CrossRef]

56. Li, Q.S.; Duan, L.J.; Estes, J.D.; Ma, Z.M.; Rourke, T.; Wang, Y.C.; Reilly, C.; Carlis, J.; Miller, C.J.; Haase, A.T. Peak SIV replication in resting memory CD4(+) T cells depletes gut lamina propria CD4(+) T cells. Nature 2005, 434, 1148-1152. [CrossRef]

57. Mattapallil, J.J.; Douek, D.C.; Hill, B.; Nishimura, Y.; Martin, M.; Roederer, M. Massive infection and loss of memory CD4(+) T cells in multiple tissues during acute SIV infection. Nature 2005, 434, 1093-1097. [CrossRef]

58. Veazey, R.S.; DeMaria, M.; Chalifoux, L.V.; Shvetz, D.E.; Pauley, D.R.; Knight, H.L.; Rosenzweig, M.; Johnson, R.P.; Desrosiers, R.C.; Lackner, A.A. Gastrointestinal tract as a major site of CD4+ T cell depletion and viral replication in SIV infection. Science 1998, 280, 427-431. [CrossRef]

59. Doitsh, G.; Greene, W.C. Dissecting how CD4 T cells are lost during HIV infection. Cell Host Microbe 2016, 19, 280-291. [CrossRef]

60. De Kleer, I.; Willems, F.; Lambrecht, B.; Goriely, S. Ontogeny of myeloid cells. Front. Immunol. 2014, 5, 432. [CrossRef]

61. Perdiguero, E.G.; Klapproth, K.; Schulz, C.; Busch, K.; Azzoni, E.; Crozet, L.; Garner, H.; Trouillet, C.; de Bruijn, M.F.; Geissmann, F.; et al. Tissue-resident macrophages originate from yolk-sac-derived erythro-myeloid progenitors. Nature 2015, 518, 547-551. [CrossRef]

62. Schulz, C.; Perdiguero, E.G.; Chorro, L.; Szabo-Rogers, H.; Cagnard, N.; Kierdorf, K.; Prinz, M.; Wu, B.S.; Jacobsen, S.E.W.; Pollard, J.W.; et al. A Lineage of myeloid cells independent of Myb and hematopoietic stem cells. Science 2012, 336, 86-90. [CrossRef] [PubMed]

63. Haase, A.T.; Henry, K.; Zupancic, M.; Sedgewick, G.; Faust, R.A.; Melroe, H.; Cavert, W.; Gebhard, K.; Staskus, K.; Zhang, Z.Q.; et al. Quantitative image analysis of HIV-1 infection in lymphoid tissue. Science 1996, 274, 985-989. [CrossRef]

64. Schmitz, J.; Vanlunzen, J.; Tennerracz, K.; Grossschupff, G.; Racz, P.; Schmitz, H.; Dietrich, M.; Hufert, F.T. Follicular dendritic cells retain HIV-1 particles on their plasma membrane, but are not productively infected in asymptomatic patients with follicular hyperplasia. J. Immunol. 1994, 153, 1352-1359.

65. Cavrois, M.; Neidleman, J.; Kreisberg, J.F.; Greene, W.C. In vitro derived dendritic cells trans-infect CD4 T cells primarily with surface-bound HIV-1 virions. PLoS Pathog. 2007, 3, 38-45. [CrossRef] [PubMed]

66. Naif, H.M.; Li, S.; Alali, M.; Sloane, A.; Wu, L.J.; Kelly, M.; Lynch, G.; Lloyd, A.; Cunningham, A.L. CCR5 expression correlates with susceptibility of maturing monocytes to human immunodeficiency virus type 1 infection. J. Virol. 1998, 72, 830-836. [CrossRef] [PubMed]

67. Baldauf, H.M.; Pan, X.Y.; Erikson, E.; Schmidt, S.; Daddacha, W.; Burggraf, M.; Schenkova, K.; Ambiel, I.; Wabnitz, G.; Gramberg, T.; et al. SAMHD1 restricts HIV-1 infection in resting CD4(+) T cells. Nat. Med. 2012, 18, 1682-1688. [CrossRef]

68. Laguette, N.; Sobhian, B.; Casartelli, N.; Ringeard, M.; Chable-Bessia, C.; Segeral, E.; Yatim, A.; Emiliani, S.; Schwartz, O.; Benkirane, M. SAMHD1 is the dendritic- and myeloid-cell-specific HIV-1 restriction factor counteracted by Vpx. Nature 2011, 474, 654-657. [CrossRef]

69. Hrecka, K.; Hao, C.L.; Gierszewska, M.; Swanson, S.K.; Kesik-Brodacka, M.; Srivastava, S.; Florens, L.; Washburn, M.P.; Skowronski, J. Vpx relieves inhibition of HIV-1 infection of macrophages mediated by the SAMHD1 protein. Nature 2011, 474, 658-661. [CrossRef] 
70. Fregoso, O.I.; Ahn, J.; Wang, C.P.; Mehrens, J.; Skowronski, J.; Emerman, M. Evolutionary toggling of Vpx/Vpr specificity results in divergent recognition of the restriction factor SAMHD1. PLoS Pathog. 2013, 9, e1003496. [CrossRef]

71. Westmoreland, S.V.; Converse, A.P.; Hrecka, K.; Hurley, M.; Knight, H.; Piatak, M.; Lifson, J.; Mansfield, K.G.; Skowronski, J.; Desrosiers, R.C. SIV Vpx Is essential for macrophage infection but not for development of AIDS. PLOS ONE 2014, 9, e84463. [CrossRef]

72. Bloch, N.; O’Brien, M.; Norton, T.D.; Polsky, S.B.; Bhardwaj, N.; Landau, N.R. HIV Type 1 infection of plasmacytoid and myeloid dendritic cells is restricted by high levels of SAMHD1 and cannot be counteracted by Vpx. AIDS Res. Hum. Retrovir. 2014, 30, 195-203. [CrossRef] [PubMed]

73. Cosenza, M.A.; Zhao, M.L.; Si, Q.S.; Lee, S.C. Human brain parenchymal microglia express CD14 and CD45 and are productively infected by HIV-1 in HIV-1 encephalitis. Brain Pathol. 2002, 12, 442-455. [CrossRef] [PubMed]

74. Neuenjacob, E.; Arendt, G.; Wendtland, B.; Jacob, B.; Schneeweis, M.; Wechsler, W. Frequency and topographical distribution of CD68-positive macrophages and HIV-1 core proteins in HIV-associated brain lesions. Clin. Neuropathol. 1993, 12, 315-324.

75. Stoler, M.H.; Eskin, T.A.; Benn, S.; Angerer, R.C.; Angerer, L.M. Human T-cell lymphotropic virus type III infection of the central nervous system. A preliminary in situ analysis. JAMA J. Am. Med. Assoc. 1986, 256, 2360-2364. [CrossRef]

76. Wiley, C.A.; Schrier, R.D.; Nelson, J.A.; Lampert, P.W.; Oldstone, M.B.A. Cellular localization of human immunodeficiency virus infection within the brains of acquired immune deficiency syndrome patients. Proc. Natl. Acad. Sci. USA 1986, 83, 7089-7093. [CrossRef] [PubMed]

77. Fischer-Smith, T.; Croul, S.; Sverstiuk, A.E.; Capini, C.; L’Heureux, D.; Regulier, E.G.; Richardson, M.W.; Amini, S.; Morgello, S.; Khalili, K.; et al. CNS invasion by CD14+/CD16+peripheral blood-derived monocytes in HIV dementia: Perivascular accumulation and reservoir of HIV infection. J. Neurovirol. 2001, 7, 528-541. [CrossRef]

78. Sturdevant, C.B.; Joseph, S.B.; Schnell, G.; Price, R.W.; Swanstrom, R.; Spudich, S. Compartmentalized replication of R5 T cell-tropic HIV-1 in the central nervous system early in the course of infection. PLoS Pathog. 2015, 11, e1004720. [CrossRef] [PubMed]

79. Duenas-Decamp, M.J.; Peters, P.J.; Burton, D.; Clapham, P.R. Determinants Flanking the CD4 Binding Loop Modulate Macrophage Tropism of Human Immunodeficiency Virus Type 1 R5 Envelopes. J. Virol. 2009, 83, 2575-2583. [CrossRef]

80. Dunfee, R.L.; Thomas, E.R.; Gorry, P.R.; Wang, J.B.; Taylor, J.; Kunstman, K.; Wolinsky, S.M.; Gabuzda, D. The HIV Env variant N283 enhances macrophage tropism and is associated with brain infection and dementia. Proc. Natl. Acad. Sci. USA 2006, 103, 15160-15165. [CrossRef]

81. Martin-Garcia, J.; Cao, W.; Varela-Robena, A.; Plassmeyer, M.L.; Gonzalez-Scarano, F. HIV-1 tropism for the central nervous system: Brain-denved envelope glycoproteins with lower CD4 dependence and reduced sensitivity to a fusion inhibitor. Virology 2006, 346, 169-179. [CrossRef]

82. Peters, P.J.; Sullivan, W.M.; Duenas-Decamp, M.J.; Bhattacharya, J.; Ankghuambom, C.; Brown, R.; Luzuriaga, K.; Bell, J.; Simmonds, P.; Ball, J.; et al. Non-macrophage-tropic human immunodeficiency virus type 1 R5 envelopes predominate in blood, lymph nodes, and semen: Implications for transmission and pathogenesis. J. Virol. 2006, 80, 6324-6332. [CrossRef] [PubMed]

83. Jambo, K.C.; Banda, D.H.; Kankwatira, A.M.; Sukumar, N.; Allain, T.J.; Heyderman, R.S.; Russell, D.G.; Mwandumba, H.C. Small alveolar macrophages are infected preferentially by HIV and exhibit impaired phagocytic function. Mucosal Immunol. 2014, 7, 1116-1126. [CrossRef] [PubMed]

84. Ganor, Y.; Real, F.; Sennepin, A.; Dutertre, C.A.; Prevedel, L.; Xu, L.; Tudor, D.; Charmeteau, B.; Couedel-Courteille, A.; Marion, S.; et al. HIV-1 reservoirs in urethral macrophages of patients under suppressive antiretroviral therapy. Nat. Microbiol. 2019, 4, 633-644. [CrossRef] [PubMed]

85. Kandathil, A.J.; Sugawara, S.; Goyal, A.; Durand, C.M.; Quinn, J.; Sachithanandham, J.; Cameron, A.M.; Bailey, J.R.; Perelson, A.S.; Balagopal, A. No recovery of replication-competent HIV-1 from human liver macrophages. J. Clin. Investig. 2018, 128, 4501-4509. [CrossRef] [PubMed] 
86. Parrish, N.F.; Wilen, C.B.; Banks, L.B.; Iyer, S.S.; Pfaff, J.M.; Salazar-Gonzalez, J.F.; Salazar, M.G.; Decker, J.M.; Parrish, E.H.; Berg, A.; et al. Transmitted/founder and chronic subtype C HIV-1 use CD4 and CCR5 receptors with equal efficiency and are not inhibited by blocking the integrin $\alpha 4 \beta 7$. PLoS Pathog. 2012, 8, e1002686. [CrossRef]

87. Ping, L.H.; Joseph, S.B.; Anderson, J.A.; Abrahams, M.R.; Salazar-Gonzalez, J.F.; Kincer, L.P.; Treurnicht, F.K.; Arney, L.; Ojeda, S.; Zhang, M.; et al. Comparison of viral Env proteins from acute and chronic infections with subtype $C$ human immunodeficiency virus type 1 identifies differences in glycosylation and CCR5 utilization and suggests a new strategy for immunogen design. J. Virol. 2013, 87, 7218-7233. [CrossRef]

88. Joseph, S.B.; Swanstrom, R. The evolution of HIV-1 entry phenotypes as a guide to changing target cells. J. Leukoc. Biol. 2018, 103, 421-431. [CrossRef]

89. Joseph, S.B.; Arrildt, K.T.; Swanstrom, A.E.; Schnell, G.; Lee, B.; Hoxie, J.A.; Swanstrom, R. Quantification of entry phenotypes of macrophage-tropic HIV-1 across a wide range of CD4 densities. J. Virol. 2014, 88, 1858-1869. [CrossRef]

90. Bruggeman, L.A.; Ross, M.D.; Tanji, N.; Cara, A.; Dikman, S.; Gordon, R.E.; Burns, G.C.; D'Agati, V.D.; Winston, J.A.; Klotman, M.E.; et al. Renal epithelium is a previously unrecognized site of HIV-1 infection. J. Am. Soc. Nephrol. 2000, 11, 2079-2087.

91. Marras, D.; Bruggeman, L.A.; Gao, F.; Tanji, N.; Mansukhani, M.M.; Cara, A.; Ross, M.D.; Gusella, G.L.; Benson, G.; D'Agati, V.D.; et al. Replication and compartmentalization of HIV-1 in kidney epithelium of patients with HIV-associated nephropathy. Nat. Med. 2002, 8, 522-526. [CrossRef]

92. Bagasra, O.; Lavi, E.; Bobroski, L.; Khalili, K.; Pestaner, J.P.; Tawadros, R.; Pomerantz, R.J. Cellular reservoirs of HIV-1 in the central nervous system of infected individuals: Identification by the combination of in situ polymerase chain reaction and immunohistochemistry. AIDS 1996, 10, 573-585. [CrossRef] [PubMed]

93. Churchill, M.J.; Wesselingh, S.L.; Cowley, D.; Pardo, C.A.; McArthur, J.C.; Brew, B.J.; Gorry, P.R. Extensive Astrocyte Infection Is Prominent in Human Immunodeficiency Virus-Associated Dementia. Ann. Neurol. 2009, 66, 253-258. [CrossRef] [PubMed]

94. Nuovo, G.J.; Alfieri, M.L. AIDS dementia is associated with massive, activated HIV-1 infection and concomitant expression of several cytokines. Mol. Med. 1996, 2, 358-366. [CrossRef] [PubMed]

95. Takahashi, K.; Wesselingh, S.L.; Griffin, D.E.; McArthur, J.C.; Johnson, R.T.; Glass, J.D. Localization of HIV-1 in human brain using polymerase chain reaction in situ hybridization and immunocytochemistry. Ann. Neurol. 1996, 39, 705-711. [CrossRef]

96. Kolchinsky, P.; Mirzabekov, T.; Farzan, M.; Kiprilov, E.; Cayabyab, M.; Mooney, L.J.; Choe, H.; Sodroski, J. Adaptation of a CCR5-using, primary human immunodeficiency virus type 1 isolate for CD4-independent replication. J. Virol. 1999, 73, 8120-8126. [CrossRef]

97. LaBranche, C.C.; Hoffman, T.L.; Romano, J.; Haggarty, B.S.; Edwards, T.G.; Matthews, T.J.; Doms, R.W.; Hoxie, J.A. Determinants of CD4 independence for a human immunodeficiency virus type 1 variant map outside regions required for coreceptor specificity. J. Virol. 1999, 73, 10310-10319. [CrossRef]

98. Hoffman, T.L.; LaBranche, C.C.; Zhang, W.T.; Canziani, G.; Robinson, J.; Chaiken, I.; Hoxie, J.A.; Doms, R.W. Stable exposure of the coreceptor-binding site in a CD4-independent HIV-1 envelope protein. Proc. Natl. Acad. Sci. USA 1999, 96, 6359-6364. [CrossRef]

99. Dumonceaux, J.; Nisole, S.; Chanel, C.; Quivet, L.; Amara, A.; Baleux, F.; Briand, P.; Hazan, U. Spontaneous mutations in the env gene of the human immunodeficiency virus type 1 NDK isolate are associated with a CD4-independent entry phenotype. J. Virol. 1998, 72, 512-519. [CrossRef]

100. Kassa, A.; Madani, N.; Schon, A.; Haim, H.; Finzi, A.; Xiang, S.H.; Wang, L.P.; Princiotto, A.; Pancera, M.; Courter, J.; et al. Transitions to and from the CD4-Bound Conformation Are Modulated by a Single-Residue Change in the Human Immunodeficiency Virus Type 1 gp120 Inner Domain. J. Virol. 2009, 83, 8364-8378. [CrossRef]

101. Sullivan, N.; Sun, Y.; Li, J.; Hofmann, W.; Sodroski, J. Replicative function and neutralization sensitivity of envelope glycoproteins from primary and T-cell line-passaged human immunodeficiency virus type 1 isolates. J. Virol. 1995, 69, 4413-4422. [CrossRef]

102. Avalos, C.R.; Abreu, C.M.; Queen, S.E.; Li, M.; Price, S.; Shirk, E.N.; Engle, E.L.; Forsyth, E.; Bullock, B.T.; Mac Gabhann, F.; et al. Brain macrophages in Simian Immunodeficiency Virus-infected, antiretroviral-suppressed macaques: A functional latent reservoir. Mbio 2017, 8, 16. [CrossRef] 
103. Beck, S.E.; Queen, S.E.; Pate, K.A.M.; Mangus, L.M.; Abreu, C.M.; Gama, L.; Witwer, K.W.; Adams, R.J.; Zink, M.C.; Clements, J.E.; et al. An SIV/macaque model targeted to study HIV-associated neurocognitive disorders. J. Neurovirol. 2018, 24, 204-212. [CrossRef] [PubMed]

104. Clements, J.E.; Gama, L.; Graham, D.R.; Mankowski, J.L.; Zink, M.C. A simian immunodeficiency virus macaque model of highly active antiretroviral treatment: Viral latency in the periphery and the central nervous system. Curr. Opin. HIV AIDS 2011, 6, 37-42. [CrossRef] [PubMed]

105. Gama, L.; Abreu, C.M.; Shirk, E.N.; Price, S.L.; Li, M.; Laird, G.M.; Pate, K.A.M.; Wietgrefe, S.W.; O'Connor, S.L.; Pianowski, L.; et al. Reactivation of simian immunodeficiency virus reservoirs in the brain of virally suppressed macaques. AIDS 2017, 31, 5-14. [CrossRef] [PubMed]

106. Micci, L.; Alvarez, X.; Iriele, R.I.; Ortiz, A.M.; Ryan, E.S.; McGary, C.S.; Deleage, C.; McAtee, B.B.; He, T.Y.; Apetrei, C.; et al. CD4 depletion in SIV-infected macaques results in macrophage and microglia infection with rapid turnover of infected cells. PLoS Pathog. 2014, 10, e1004467. [CrossRef]

107. Nowlin, B.T.; Burdo, T.H.; Midkiff, C.C.; Salemi, M.; Alvarez, X.; Williams, K.C. SIV encephalitis lesions are composed of CD163(+) macrophages present in the central nervous system during early SIV infection and SIV-positive macrophages recruited terminally with AIDS. Am. J. Pathol. 2015, 185, 1649-1665. [CrossRef]

108. Daniel, M.D.; Letvin, N.L.; King, N.W.; Kannagi, M.; Sehgal, P.K.; Hunt, R.D.; Kanki, P.J.; Essex, M.; Desrosiers, R.C. Isolation of T-cell tropic HTLV-III-like retrovirus from macaques. Science 1985, 228, 1201-1204. [CrossRef]

109. Naidu, Y.M.; Kestler, H.W.; Li, Y.; Butler, C.V.; Silva, D.P.; Schmidt, D.K.; Troup, C.D.; Sehgal, P.K.; Sonigo, P.; Daniel, M.D.; et al. Characterization of infectious molecular clones of simian immunodeficiency virus (SIVmac) and human immunodeficiency virus type 2: Persistent infection of rhesus monkeys with molecularly cloned SIVmac. J. Virol. 1988, 62, 4691-4696. [CrossRef]

110. Miller, C.J.; Marthas, M.; Greenier, J.; Lu, D.; Dailey, P.J.; Lu, Y.C. In vivo replication capacity rather than in vitro macrophage tropism predicts efficiency of vaginal transmission of simian immunodeficiency virus or simian/human immunodeficiency virus in rhesus macaques. J. Virol. 1998, 72, 3248-3258. [CrossRef]

111. Ortiz, A.M.; Klatt, N.R.; Li, B.; Yi, Y.; Tabb, B.; Hao, X.P.; Sternberg, L.; Lawson, B.; Carnathan, P.M.; Cramer, E.M.; et al. Depletion of CD4(+) T cells abrogates post-peak decline of viremia in SIV-infected rhesus macaques. J. Clin. Investig. 2011, 121, 4433-4445. [CrossRef]

112. Abreu, C.M.; Veenhuis, R.T.; Avalos, C.R.; Graham, S.; Parrilla, D.R.; Ferreira, E.A.; Queen, S.E.; Shirk, E.N.; Bullock, B.T.; Li, M.; et al. Myeloid and CD4 T Cells Comprise the Latent Reservoir in Antiretroviral Therapy-Suppressed SIVmac251-Infected Macaques. Mbio 2019, 10, e1659-19. [CrossRef]

113. Kestler, H.; Kodama, T.; Ringler, D.; Marthas, M.; Pedersen, N.; Lackner, A.; Regier, D.; Sehgal, P.; Daniel, M.; King, N.; et al. Induction of AIDS in rhesus monkeys by molecularly cloned simian immunodeficiency virus. Science 1990, 248, 1109-1112. [CrossRef] [PubMed]

114. Banapour, B.; Marthas, M.L.; Ramos, R.A.; Lohman, B.L.; Unger, R.E.; Gardner, M.B.; Pedersen, N.C.; Luciw, P.A. Identification of viral determinants of macrophage tropism for simian immunodeficiency virus SIVmac. J. Virol. 1991, 65, 5798-5805. [CrossRef] [PubMed]

115. Borda, J.T.; Alvarez, X.; Kondova, I.; Aye, P.; Simon, M.A.; Desrosiers, R.C.; Lackner, A.A. Cell tropism of simian immunodeficiency virus in culture is not predictive of in vivo tropism or pathogenesis. Am. J. Pathol. 2004, 165, 2111-2122. [CrossRef]

116. Ryzhova, E.V.; Crino, P.; Shawver, L.; Westmoreland, S.V.; Lackner, A.A.; Gonzalez-Scarano, F. Simian immunodeficiency virus encephalitis: Analysis of envelope sequences from individual brain multinucleated giant cells and tissue samples. Virology 2002, 297, 57-67. [CrossRef] [PubMed]

117. Desrosiers, R.C.; Hansenmoosa, A.; Mori, K.; Bouvier, D.P.; King, N.W.; Daniel, M.D.; Ringler, D.J. Macrophage-tropic variants of SIV are associated with specific AIDS-related lesions but are not essential for the development of AIDS. Am. J. Pathol. 1991, 139, 29-35.

118. Mori, K.; Ringler, D.J.; Kodama, T.; Desrosiers, R.C. Complex determinants of macrophage tropism in env of simian immunodeficiency virus. J. Virol. 1992, 66, 2067-2075. [CrossRef]

119. Zink, M.C.; Amedee, A.M.; Mankowski, J.L.; Craig, L.; Didier, P.; Carter, D.L.; Munoz, A.; MurpheyCorb, M.; Clements, J.E. Pathogenesis of SIV encephalitis-Selection and replication of neurovirulent SIV. Am. J. Pathol. 1997, 151, 793-803. 
120. Flaherty, M.T.; Hauer, D.A.; Mankowski, J.L.; Zink, M.C.; Clements, J.E. Molecular and biological characterization of a neurovirulent molecular clone of simian immunodeficiency virus. J. Virol. 1997, 71, 5790-5798. [CrossRef]

121. Mankowski, J.L.; Flaherty, M.T.; Spelman, J.P.; Hauer, D.A.; Didier, P.J.; Amedee, A.M.; MurpheyCorb, H.; Kirstein, L.M.; Munoz, A.; Clements, J.E.; et al. Pathogenesis of simian immunodeficiency virus encephalitis: Viral determinants of neurovirulence. J. Virol. 1997, 71, 6055-6060. [CrossRef]

122. Clements, J.E.; Babas, T.; Mankowski, J.L.; Suryanarayana, K.; Piatak, M.; Tarwater, P.M.; Lifson, J.D.; Zink, M.C. The central nervous system as a reservoir for Simian immunodeficiency virus (SIV): Steady-state levels of SIV DNA in brain from acute through asymptomatic infection. J. Infect. Dis. 2002, 186, 905-913. [CrossRef] [PubMed]

123. Zink, M.C.; Suryanarayana, K.; Mankowski, J.L.; Shen, A.D.; Piatak, M.; Spelman, J.P.; Carter, D.L.; Adams, R.J.; Lifson, J.D.; Clements, J.E. High viral load in the cerebrospinal fluid and brain correlates with severity of simian immunodeficiency virus encephalitis. J. Virol. 1999, 73, 10480-10488. [CrossRef] [PubMed]

124. Hirsch, V.; AdgerJohnson, D.; Campbell, B.; Goldstein, S.; Brown, C.; Elkins, W.R.; Montefiori, D.C. A molecularly cloned, pathogenic, neutralization-resistant simian immunodeficiency virus, SIVsmE543-3. J. Virol. 1997, 71, 1608-1620. [CrossRef] [PubMed]

125. Matsuda, K.; Dang, Q.; Brown, C.R.; Keele, B.F.; Wu, F.; Ourmanov, I.; Goeken, R.; Whitted, S.; Riddick, N.E.; Buckler-White, A.; et al. Characterization of simian immunodeficiency virus (SIV) that induces SIV encephalitis in rhesus macaques with high frequency: Role of TRIM5 and major histocompatibility complex genotypes and early entry to the brain. J. Virol. 2014, 88, 13201-13211. [CrossRef] [PubMed]

126. Matsuda, K.; Riddick, N.E.; Lee, C.A.; Puryear, S.B.; Wu, F.; Lafont, B.A.P.; Whitted, S.; Hirsch, V.M. A SIV molecular clone that targets the CNS and induces neuroAIDS in rhesus macaques. PLoS Pathog. 2017, 13, e1006538. [CrossRef] [PubMed]

127. Matsuda, K.; Brown, C.R.; Foley, B.; Goeken, R.; Whitted, S.; Dang, Q.; Wu, F.; Plishka, R.; Buckler-White, A.; Hirscha, V.M. Laser capture microdissection assessment of virus compartmentalization in the central nervous systems of macaques infected with neurovirulent simian immunodeficiency virus. J. Virol. 2013, 87, 8896-8908. [CrossRef]

128. Means, R.E.; Matthews, T.; Hoxie, J.A.; Malim, M.H.; Kodama, T.; Desrosiers, R.C. Ability of the v3 loop of simian immunodeficiency virus to serve as a target for antibody-mediated neutralization: Correlation of neutralization sensitivity, growth in macrophages, and decreased dependence on CD4. J. Virol. 2001, 75, 3903-3915. [CrossRef]

129. Arrildt, K.T.; LaBranche, C.C.; Joseph, S.B.; Dukhovlinova, E.N.; Graham, W.D.; Ping, L.-H.; Schnell, G.; Sturdevant, C.B.; Kincer, L.P.; Mallewa, M.; et al. Phenotypic correlates of HIV-1 macrophage tropism. J. Virol. 2015, 89, 11294-11311. [CrossRef]

130. Francella, N.; Elliott, S.T.C.; Yi, Y.J.; Gwyn, S.E.; Ortiz, A.M.; Li, B.; Silvestri, G.; Paiardini, M.; Derdeyn, C.A.; Collman, R.G. Decreased plasticity of coreceptor use by CD4-independent SIV Envs that emerge in vivo. Retrovirology 2013, 10, 133. [CrossRef]

131. Decker, J.M.; Bibollet-Ruche, F.; Wei, X.P.; Wang, S.Y.; Levy, D.N.; Wang, W.Q.; Delaporte, E.; Peeters, M.; Derdeyn, C.A.; Allen, S.; et al. Antigenic conservation and immunogenicity of the HIV coreceptor binding site. J. Exp. Med. 2005, 201, 1407-1419. [CrossRef]

132. Chahroudi, A.; Bosinger, S.E.; Vanderford, T.H.; Paiardini, M.; Silvestri, G. Natural SIV hosts: Showing AIDS the door. Science 2012, 335, 1188-1193. [CrossRef] [PubMed]

133. Chen, Z.W.; Gettie, A.; Ho, D.D.; Marx, P.A. Primary SIVsm isolates use the CCR5 coreceptor from sooty mangabeys naturally infected in west Africa: A comparison of coreceptor usage of primary SIVsm, HIV-2, and SIVmac. Virology 1998, 246, 113-124. [CrossRef] [PubMed]

134. Fomsgaard, A.; Johnson, P.R.; Nielsen, C.; Novembre, F.J.; Hansen, J.; Goldstein, S.; Hirsch, V.M. Receptor function of CD4 structures from African green monkey and pig-tail macaque for simian immunodeficiency virus, SIVsm, SIVagm, and human immunodeficiency virus type-1. Viral Immunol. 1995, 8, 121-133. [CrossRef] [PubMed]

135. Zhang, Y.J.; Lou, B.; Lal, R.B.; Gettie, A.; Marx, P.A.; Moore, J.P. Use of inhibitors to evaluate coreceptor usage by simian and simian/human immunodeficiency viruses and human immunodeficiency virus type 2 in primary cells. J. Virol. 2000, 74, 6893-6910. [CrossRef] 
136. Klatt, N.R.; Villinger, F.; Bostik, P.; Gordon, S.N.; Pereira, L.; Engram, J.C.; Mayne, A.; Dunham, R.M.; Lawson, B.; Ratcliffe, S.J.; et al. Availability of activated CD4(+) T cells dictates the level of viremia in naturally SIV-infected sooty mangabeys. J. Clin. Investig. 2008, 118, 2039-2049. [CrossRef]

137. Kunstman, K.J.; Puffer, B.; Korber, B.T.; Kuiken, C.; Smith, U.R.; Kunstman, J.; Stanton, J.; Agy, M.; Shibata, R.; Yoder, A.D.; et al. Structure and function of CC-chemokine receptor 5 homologues derived from representative primate species and subspecies of the taxonomic suborders Prosimii and Anthropoidea. J. Virol. 2003, 77, 12310-12318. [CrossRef]

C 2020 by the authors. Licensee MDPI, Basel, Switzerland. This article is an open access article distributed under the terms and conditions of the Creative Commons Attribution (CC BY) license (http://creativecommons.org/licenses/by/4.0/). 